\title{
8 Reduced acrimony, quiet management
}

\section{Intergovernmental relations during the COVID-19 pandemic in Canada}

\author{
André Lecours, Daniel Béland and \\ Jennifer Wallner
}

\subsection{Introduction}

Federalism is a defining feature of Canada both as a political system and a community of peoples (Smiley 1987). Accordingly, the country's experience of the COVID-19 pandemic was very much mediated by the rules and practices of the federal system. The virus hit the westernmost province of British Columbia first but eventually affected the two largest provinces of Québec and Ontario most. Federalism allowed provincial and territorial governments to tailor the response to the pandemic to particular situations. At the same time, the federal government enacted country-wide measures to contain the spread of the virus, like closing the international border with the United States and introducing key income replacement measures to mitigate the socio-economic consequences of the pandemic. There was a unity and diversity quality to Canada's response to the pandemic.

Interestingly, Canada's often acrimonious intergovernmental relations calmed down during the first wave of the pandemic, as some Premiers historically at odds with Prime Minister Justin Trudeau found political incentives to collaborate. Indeed, approval ratings of virtually every Premier rose in the Spring of 2020 (Dart \& Maru/ Blue 2020). A good degree of intergovernmental collaboration facilitated Canada's response to COVID-19.

This chapter first paints the picture of the health and socio-economic impact of COVID-19 on the Canadian federation. It then details the role played by the two orders of government in the response to the virus and analyzes how a combination of structural and circumstantial factors helped keep intergovernmental conflict low. Finally, the chapter explains how the pandemic has increased, probably temporarily, the frequency of intergovernmental contacts, which have occurred along the lines of pre-existing structures and practices unlikely to be fundamentally transformed by the fight against the virus (Table 8.1).

Table 8.1 Key Statistics on COVID-19 in Canada as of 10 January 2021

\begin{tabular}{lllll}
\hline $\begin{array}{l}\text { Cumulative } \\
\text { Cases }\end{array}$ & $\begin{array}{l}\text { Cumulative Cases per } \\
100,000 \text { Population }\end{array}$ & $\begin{array}{l}\text { Cumulative } \\
\text { Deaths }\end{array}$ & $\begin{array}{l}\text { Cumulative Deaths per } \\
100,000 \text { Population }\end{array}$ & $\begin{array}{l}\text { Case Fatality } \\
\text { Percentage }\end{array}$ \\
\hline 644,348 & $1,707.2$ & 16,707 & 44.3 & 2.6
\end{tabular}

Source: World Health Organization Weekly epidemiological update - 12 January 2021. Geneva: WHO, 2021. Available from https://www.who.int/publications/m/item/weekly-epidemiological-update 


\subsection{The health and economic impact of COVID-19}

COVID-19 had a significant impact on Canada's public health and economic situation. As of 19 January 2021, Canada had registered nearly 720,000 detected COVID-19 cases. ${ }^{1}$ The number of cases varied greatly from one province to the next. For instance, Quebec, the country's second largest province (8.6 million inhabitants), had the highest number of detected cases $(245,734)$. Ontario, the largest province by far (14.7 million inhabitants), registered the second largest number of cases $(242,277)$. Among the four most populous provinces (Alberta, British Columbia, Ontario, and Quebec), British Columbia performed the best in controlling the number of cases. In part because of pro-active public health measures enacted early on, it only registered 61,912 cases, which is good considering its population of about 5 million. Among the less populous provinces, the four Atlantic Provinces (Newfoundland and Labrador, New Brunswick, Nova Scotia, and Prince Edward Island) did much better than Manitoba and Saskatchewan, becoming the most successful region of the country in the fight against the pandemic, with the exception of the three territories, which were unevenly affected by it (relatively few cases in the Northwest Territory and Yukon but a more challenging situation in Nunavut, at least during the second wave of the pandemic). Overall, some regions of the country were more affected by the virus than others, something that is attributed to a mixture of factors, including exposure to international travel, population density as well as the nature and timing of policy decisions about issues such as quarantine, self-insolation, and the staffing of longterm care facilities, where more than two-third of infected people died and close to a quarter of all Canadians who have tested positive for COVID-19 lived. This situation has triggered a national debate about long-term care policies in Canada (Béland and Marier 2020).

Like in many other countries, the pandemic and the public health measures enacted in response to COVID-19 have created a sudden economic downturn in Canada. For example, during the second quarter of 2020, "the economy is estimated to have plunged 39.8 percent," a dramatic and unprecedented development (Deloitte 2020, p. 5). For the year 2020, a downturn of nearly 6 percent was expected. Some sectors of the economy were hit especially hard, including accommodation and food services, construction, manufacturing, retail, arts, entertainment, and recreation (Deloitte 2020). Because of a sharp decline of economic activity in these key areas, unemployment increased rapidly. From February to March 2020, the national unemployment rate jumped from 5.6 to 7.8 percent before reaching 13 percent in April and 13.7 percent in May. In part, because of a gradual and partial reopening of key sectors of the economy, the unemployment rate declined slightly in June to reach 12.3 percent, which was still more than twice as high as the figure for February. Simultaneously, while the economic shock affected the entire country, as was the case for the pandemic itself, some demographics such as women, were more affected by the economic downturn and the job losses (Wright 2020). Regional variation also proved significant. For example, in Alberta, a province already facing economic difficulties before the COVID-19 crisis due in part to lower oil prices, unemployment increased rapidly from 7.2 percent in February to 15.5 percent in May, and it did not decline in June, as it did nationally and in most other provinces. Although the economy recovered partly during the summer and fall of 2020, the national unemployment rate sat at 8.5 percent in November, which is much higher than before the pandemic. 
Such a swift economic downturn led to the rapid enactment of temporary yet massive federal emergency measures to help families, workers, and employers despite the presence of a minority government in Ottawa. These expensive, large-scale measures, coupled with massive revenue loses, led to a sudden and unprecedented increase in the size of the federal deficit, which is anticipated to reach 381 billion dollars CDN in 2020-2021 compared to only 14 billion dollars CDN in 2018-2019 and 34.4 billion CDN in 2019-2020. A possible second wave of COVID-19 could slow down a revenue-generating economic recovery while pressuring the federal government to spend even more on emergency economic and social policy measures, a situation that would further increase the federal deficit. As far as fiscal challenges are concerned, the provinces, territories, and municipalities are especially vulnerable, a situation leading to calls to reform fiscal federalism in order to help these governments struggling to pay growing bills with lower revenues and a fiscal capacity much more limited than the federal government's (Béland et al. 2020). There is significant variation in the fiscal situation of provincial governments. For instance, while a poorer province facing a resource bust like Newfoundland and Labrador is in a dire situation, a wealthier one like British Columbia is in a much better position to weather the crisis. Still, calls to reform fiscal federalism and, in effect, to increase federal transfers to the provinces in key areas such as health care and long-term care are getting louder (Béland et al. 2020).

\subsection{The intergovernmental management of the pandemic}

Canada is a decentralized federation both from a public policy and a fiscal point of view (Lecours 2019). The ten provinces have exclusive or primary legislative and administrative power in the fields of education, health care, employment relations, civil law, law enforcement, and natural resources. The federal government has exclusive or primary legislative and administrative power in the fields of currency, defense, agriculture, citizenship and immigration, foreign affairs, criminal law, and employment insurance. From a fiscal perspective, approximately 80 percent of provincial revenues are own-source, and the major fiscal transfers from the federal government are either unconditional (equalization) or very weakly conditional (the Canada Health Transfer $[\mathrm{CHT}]$ and the Canada Social Transfer [CST]). The three territories have powers similar to those of provinces but no constitutional existence, as they owe their autonomy to the Parliament of Canada rather than to a constitutional division of powers. Municipalities also lack constitutional standing; they are under the authority of provincial governments.

Health care and emergency management were foremost fields of jurisdiction during the pandemic. Health care, in all its forms, is a provincial responsibility. Provincial health care systems have to conform to broad principles contained in the 1984 federal Canada Health Act and the federal government funds about 20 percent of provincial health care costs through the CHT. There are no specific emergency management powers listed in the Canadian Constitution aside from the federal authority over quarantine (British North America Act, section 91-11), which was not invoked by the federal government during the pandemic. Similarly, the federal Emergencies Act was not invoked, after provincial governments clearly signaled they considered such a move unnecessary. There is a federal Disaster Financial Assistance Arrangements program, but it explicitly excludes pandemics. 
Both orders of government played important roles during the pandemic. ${ }^{2}$ On public health, provinces were on the front lines, managing the health care system and longterm care homes; deciding on confinement and de-confinement as well as on the use of masks in indoor public spaces; controlling movement within their territory as well as to and from other provinces; and choosing when to close and open schools as well as how to structure learning in the exceptional circumstances. Provinces also decided on the opening and closure of businesses, and some of them formed regional 'bubbles' for the purpose of inter-provincial movement. The federal government managed international travel and the border with the United States. It also oversaw vaccine development efforts and procurement. Moreover, at the request of the Québec and Ontario governments, it deployed members of the Canadian Armed Forces in the two provinces' long-term care homes. Most of the federal government's action focused on mitigating the economic impact of the pandemic through temporary programs that included the Canada Emergency Response Benefits (CERB) to support the unemployed; the Canada Emergency Student Benefit (CESB), to support post-secondary students; and the Canada Emergency Wage Subsidy (CEWS), to help employers rehire laid off workers. Provinces were generally receptive to these temporary programs, even if they were sometimes not given much forewarning before their announcement and implementation. Some provincial governments formulated smaller and complementary, assistance programs (for example, Québec developed an incentive program for retaining workers deemed essential during the pandemic such as grocery stores employees). Overall, the management of both the public health and the economic dimensions of the pandemic occurred in respect of the constitutional division of powers. Typical of Canadian federalism, when the federal government sought to impose conditions for a special one-time transfer of almost 20 billion dollars CAN, the provinces pushed back to reduce or outright eliminate these conditions (Marquis 2020).

Although the federal government possesses a fiscal might far superior to that of the provinces, the large federal deficit generated by the creation of numerous, and sometimes far-reaching, temporary programs will place the federal government in Ottawa in a difficult fiscal position for years to come. In the context of such large budgetary deficits, any effort to centralize the economy in anyway is highly unlikely. Instead, provinces have already shown their intention to double-down on their traditional demand for an increase in federal transfers for health care; the catastrophic situation in long-term care homes in Ontario and, especially, Québec seems to have provided new ammunitions to provincial governments in their pursuit of increased health care funding (Béland and Marier 2020).

Intergovernmental relations during the pandemic were generally harmonious and collaborative. This is somewhat surprising considering that federal-provincial relations were quite tense just before the pandemic. Several of the country's Conservative Premiers (Doug Ford of Ontario, Jason Kenney of Alberta, and Scott Moe of Saskatchewan) had openly attacked Liberal Prime Minister Justin Trudeau for his carbon-taxing policy and his perceived reluctance to develop pipeline capacity to transport oil from producing provinces (primarily Alberta) to the Canadian West and East coasts, where it could then be taken to Asian and European markets, respectively (Béland and Lecours, forthcoming). Québec's conservative nationalist Premier François Legault (Coalition Avenir Québec) had publicly rowed with Trudeau over his province's secularism legislation, which the Prime Minister criticized. Yet, during the first wave of the pandemic, most of these Premiers refrained from any serious 
criticism of the federal government, with some even praising the federal government and collaborating in intergovernmental relations (Grenier 2020). ${ }^{3}$

At least three factors explain how Canada was able to have low intergovernmental conflict during the pandemic. First, Canadian political parties are overall weakly integrated through the levels of government, with the federal and provincial Conservative parties not being integrated at all (Thorlakson 2009). Consequently, Conservative Premiers were not structurally driven to oppose the federal Liberal government for the purpose of helping the federal Conservative party to score political points. As the pandemic offered a chance for some Conservative Premiers to improve their approval rating in their province, they were free to adopt a collaborative approach with the federal government if they judged it could help them politically. ${ }^{4}$

Second, Canada's parliamentary system allowed the Prime Minister to use the tools of Cabinet government (Lijphart 2012, p. 10) to conduct relations with Premiers with whom he had previous or ongoing tensions. For example, Trudeau tasked a powerful minister in his cabinet from Ontario, Chrystia Freeland (Minister of Intergovernmental Affairs and also Deputy Prime Minister, before becoming Minister of Finance), to assume primary responsibility for relations with that provincial government. ${ }^{5}$ Moreover, the federal Liberal government's parliamentary minority (a relatively uncommon situation in Canada) provided incentives to forge harmonious intergovernmental relations, with the expectation of either prolonging the life of the minority government (notoriously short in Canada) or placing the Liberals in a good position to gain a majority at the next elections. For the federal government, reducing conflict with the provinces typically involves refraining from unilateral action, national standards, and conditional transfers. Prime Minister Trudeau often stated that the federal government was there to help provinces in whichever way it could, presenting a supportive yet not overbearing position.

Third, the existence of a dense network of federal-provincial relations (especially at the bureaucratic level) facilitated the transition toward more intense intergovernmental contact. At the political level, intergovernmental relations have long been dominated almost exclusively by executives; as such, so-called executive federalism is an important element of continuity in the Canadian federation (Wallner 2017). The practice of First Ministers Meetings (typically, but not always, held annually), which is at the apex of executive federalism, served as a template for the weekly conversation between Canada's Prime Minister and provincial Premiers. These conversations, though largely dedicated to information-sharing, produced some coordination in the response to COVID-19, which allowed Canada to have an overall effective management of the pandemic. They facilitated greater inter-provincial communication than is typically the case in Canadian federalism, as provincial governments could explore opportunities for common positions on different aspects of the management of the pandemic, including the closing/opening of the border with the United States, procurement of medical and testing equipment, and the possibility of the federal government invoking the Emergencies Act. In addition to consensus-seeking negotiations and information-sharing, inter-provincial relations also included instances of material collaboration (e.g., Alberta donating medical equipment to other provinces).

Provincial governments played a prominent role during the pandemic. Their constitutional powers over health care, education, municipal institutions, and private property allowed them to be the main decision-makers on many questions that directly impacted the everyday life of Canadians. The room for autonomous action by 
municipalities depended upon the specific governance approach of the province since municipalities are constitutionally required to operate within the provincial legislative framework. For example, on masks in indoor public spaces, the Québec government issued an order for compulsory use effective 11 July 2020 while the Ontario government left that decision up to municipal and local authorities.

Federalism performed well in Canada during the first wave of the pandemic, as autonomous federal and provincial action structured by the constitutional division of powers was complemented by increased intergovernmental communication and information-sharing. Canada was created as a federation, and just like it is unimaginable to think of this multinational state (Burgess and Pinder 2011) as anything but federal in normal times, it is equally unthinkable that it would have performed better, or as well, without federalism during the COVID-19 crisis. The virus affected regions of the country quite differently, and federalism allowed for responses tailored to specific situations to be implemented.

\subsection{Innovations, transformations, and missed opportunities in IGR}

There can be no denying the fact that the effort to contend with the COVID-19 pandemic has transformed the frequency of intergovernmental meetings in Canada. As soon as the lockdown was announced on 13 March 2020, the Prime Minister and the Premiers met weekly via telephone conference calls. In December 2020, the Prime Minister also convened a formal First Ministers' Meeting on fighting COVID-19 and strengthening health care. For the most part, during the first wave of the pandemic, many Premiers voiced largely positive responses in reaction to the efforts of the Prime Minister and members of his government. As noted above, Deputy Prime Minister Chrystia Freeland received considerable positive feedback from various Premiers.

Disagreements have nevertheless arisen in some unexpected ways. For example, the effort to mobilize technology and create a voluntary contact tracing application in Canada has been complicated by intergovernmental conflict. Specifically, the federal government has been working to create a centralized, 'national' application while individual provinces and territories launched similar initiatives. On 19 June 2020, CBC News reported that New Brunswick Premier Blaine Higgs was told to stop working on a provincial app in favor of a single federally backed application using Bluetooth technology provided jointly by Apple and Google (MacKinnon 2020). And, on 13 July 2020, Alberta Premier Jason Kenney accused the federal government of preventing tech companies from working with provinces to improve contact tracing apps (Major 2020). This example exposes the classic blame avoidance or buck-passing dynamic long associated with intergovernmental relations in federations.

This pandemic also marks the first time we see the rise of personal communications among politicians in addition to the concerted use of social media to communicate intergovernmental responses to a major emergency. To start, a growing number of politicians are eschewing the traditional formal lines of communication, set through staff, in favor of rapid texting and Blackberry phone calls. Premier Doug Ford, for example, has been calling and checking in with Minister Chrystia Freeland virtually every other day since the early days of the pandemic in March 2020 (Hains 2020). The Premiers who are most sympathetic to the federal government re-tweeted and posted information from the Government of Canada rather than drawing upon their own provincial resources. For example, the Premier of 


\section{André Lecours et al.}

Newfoundland and Labrador regularly posted content drawn from federal ministers and the Chief Public Health Officer, unlike the Premier of Saskatchewan who did not post or re-tweet anything with content from the Government of Canada. However, as also noted above, even the most combative Premiers toned down their rhetoric throughout the pandemic and scaled back the frequency of their critiques against the federal government.

One of the most striking responses to the pandemic was the intermittent closures of internal borders enacted by provincial and territorial governments under the auspices of public health. This is a marked and a dramatic departure from the long-standing guarantee of internal mobility rights throughout the federation. Interestingly, throughout the first wave of the pandemic, Ontario was the lone province that did not impose generalized border restrictions for interprovincial travel or requirements to self-isolate if visiting from another region in the country. What is more, in the lead-up to the First Ministers Meeting held in December 2020, Premier Doug Ford started publicly asking whether or not the federal government would move from the mandatory 14-day quarantine to rapid testing of new arrivals to expedite the reopening of borders (McGrath 2020). Others, however, have installed varied arrangements, tailored to local needs, establishing regionalized practices that carved out specific areas of the country. Atlantic Canada created a 'regional bubble,' while Manitoba postponed some of its plans to ease restrictions in response to public feedback to its proposals. Specifically, as reported by Cameron MacLean (2020), the plan included relaxing the 14-day self-isolation requirement for travelers from eastern and southern Ontario, Quebec, and Atlantic Canada. However, overwhelming responses from Manitobans indicated that the public wanted to see the restrictions remain in place, and so the Manitoba government opted to maintain the status quo. What is remarkable here is that all of these provisions and restrictions on internal mobility have been enacted largely without any controversy or conflict. It is a clear indicator of the seriousness with which Canadians took the need to stop the spread of the COVID-19 virus.

As Canada is deep into the 'second wave' of the pandemic and now facing the challenges of vaccinating the population, while managing existing infections and trying to hold off the increasingly contagious iterations of COVID-19 emerging around the world, a series of missed opportunities are apparent. Throughout the first wave of the pandemic and into the period of uncertain stability of a 'new normal,' little has been heard from the sectoral level tables or the Council of the Federation (COF), a body composed of 13 provincial and territorial Premiers created to strengthen horizontal cooperation. Traditionally the workhorses of intergovernmental relations in Canada, according to the Canadian Intergovernmental Conference Secretariat, while teleconferences and videoconferences for various tables have occurred throughout the first wave, only a few public statements have been released. In the meantime, despite issuing a few intermittent statements, the provincial and territorial Premiers decided to forgo the annual meeting of the COF, indirectly (and likely unintentionally) confirming to outside observers that the COF is essentially a body to coordinate lobbying efforts as opposed to mobilizing meaningful horizontal collaboration. Moving forward, researchers will need to determine if decision-makers and public officials throughout the country used this period to bolster the capacity of these bodies, share valuable information, develop coherent strategies, and begin to anticipate future problems as Canada and the world adapts to a new reality. 
Canadians are also learning that some provincial decisions about how to mobilize federal funds and vaccinate residents vary considerably. Since the start of the pandemic, the Premiers were clear in their opposition to any notion of the federal government enacting the Emergencies Act: "That's not their jurisdiction," said Premier Ford in response to a question posed by a journalist. "We don't need the nanny state telling us what to do" (quoted in McGrath 2020, n.p.). Consequently, money transferred by the federal government to the provinces for COVID-19 health spending, support for employers or individuals, and a general contingency fund, arrived without any strings. While some provinces may have used the money allocated to them, according to the Globe and Mail, Ontario was still holding onto $\$ 12$ billion in contingency funds when the second wave hit in the Fall of 2020 (Gray 2020). During the First Ministers Meeting in December, the federal government committed to covering 100 percent of the cost of procuring the vaccine and the supplies needed for vaccination. That month, as vaccines arrived in the country, provinces began to administer them. However, decisions on whom, when, and how to administer vaccines showed signs of inconsistency and a general lack of clear details in terms of the overall roll-out and execution strategies (The Canadian Press 2020). Assuring the efficient and effective vaccination of Canadians is a critical step in combatting this pandemic. The use of the contingency funds afforded by the federal government to provinces in order to insure, for example, the safety of children in schools and essential workers who cannot work from home, could have been more clearly detailed by provincial and territorial governments to their populations.

\subsection{Conclusion}

Overall, certain elements of federalism appear to have worked well, especially during the first wave of the COVID-19 pandemic. Using its superior fiscal clout, the federal government moved quickly to enact new economic measures to support individual Canadians and certain economic sectors through the shutdown. Furthermore, additional grants were issued to provinces and territories to support re-opening. Provinces and territories, in the meantime, found ways to curb the spread of the virus within their respective populations. Missteps certainly occurred, particularly on long-term care homes, and some provinces did a much better job than others in the terms of public health measures. Yet, federalism and intergovernmental relations worked relatively well during the pandemic, which helped mitigate its impact on Canadians. The discourse among political leaders was also generally positive through the first wave of the pandemic, though it remains unclear if such agreeable relations will remain in place subsequently. What is certain is that Canada's federal system needs to continue to find ways to foster intergovernmental collaboration in order to facilitate the implementation of policies necessary to navigate future public health and economic challenges.

\section{Notes}

1 Unless indicated, all the statistics in this section were retrieved from federal government (including Statistics Canada) websites in January 2020.

2 Municipalities' school boards and local public health officials implemented and adapted provincial directives. 
3 That was the case for Ontario's Doug Ford and Alberta's Jason Kenney. Québec Premier François Legault thanked Prime Minister Trudeau for accepting to deploy the Canadian Armed Forces in the province's long-term retirement homes.

4 This was the case for Doug Ford who was unpopular in Ontario until the pandemic.

5 Premier Ford then spoke glowingly of Minister Freeland and the job she was doing.

\section{Bibliography}

Béland, D. and Lecours, A., [Forthcoming]. L'Alberta, l'aliénation de l'Ouest et le programme fédéral de péréquation: identités territoriales, cadrage idéologique et inscription à l'agenda politique. Politique et Sociétés.

Béland, D., Lecours, A., Paquet, M. and Tombe, T., 2020. A Critical Juncture in Fiscal Federalism? Canada's Response to COVID-19. Canadian Journal of Political Science [online]. Available from: https://www.cambridge.org/core/journals/canadian-journal-of-politicalscience-revue-canadienne-de-science-politique/article/critical-juncture-in-fiscal-federalismcanadas-response-to-covid19/E4F8184DACB186C41C1E8839A7A89BB6 [Accessed 8 March 2021].

Béland, D. and Patrik, M., 2020. COVID-19 and Long-Term Care Policy for Older People in Canada. Journal of Aging \& Social Policy, 32 (4-5), 358-364.

Burgess, M. and Pinder, J., eds, 2011. Multinational Federations. London: Routledge.

Dart \& Maru/Blue Voice Canada Poll, 2020. Canadian Premiers' Quarterly Approval Rating Tracking, Q2 June. Available from: https://dartincom.ca/wp-content/uploads/2020/06/ Premiers-Release-Chart-Q2-F-2020-.pdf [Accessed 8 March 2021].

Deloitte, 2020. Unprecedented in Every Way; Economic Outlook: June 2020. Toronto: Deloitte Canada. Available from: https://www2.deloitte.com/content/dam/Deloitte/ca/ Documents/finance/ca-economic-outlook-report-june-2020-aoda-en.pdf?icid=juneReport_ en [Accessed 8 March 2021].

Gray, J., 2020. Ontario Had \$12-Bilion in Unspent Contingency Funds as COVID-19's Second Wave Hit, Report Says [online]. Globe and Mail, 8 December. Available from: https:// www.theglobeandmail.com/canada/article-ontario-had-12-billion-in-contingency-fundsas-covid-19s-second-wave/ [Accessed 8 March 2021].

Grenier, É., 2020. The Pandemic Is Breaking Down Political Barriers between Provincial and Federal Governments [online]. CBC News, 5 April. Available from: https://www.cbc.ca/ news/politics/grenier-provincial-federal-cooperation-1.5521531 [Accessed 8 March 2021].

Hains, D., 2020. How Doug Ford and Chrystia Freeland Became Canada's Political Odd Couple [online]. iPolitics, 28 December. Available from: https://ipolitics.ca/2020/12/28/howdoug-ford-and-chrystia-freeland-became-canadas-political-odd-couple/ [Accessed $8 \mathrm{March}$ 2021].

Lecours, A., 2019. Dynamic De/centralization in Canada, 1867-2010. Publius: The Journal of Federalism, 49 (1), 57-83.

Lijphart, A., 2012. Patterns of Democracy: Government Forms and Performance in ThirtySix Countries. 2nd ed. New Haven: Yale University Press.

MacKinnon, B., 2020. Province's Plans for COVID-19 Contact-tracing App Denied by Ottawa [online]. CBC News, 19 June. Available from: https://www.cbc.ca/news/canada/newbrunswick/covid-19-contact-tracing-app-new-brunswick-national-1.5618973 [Accessed 8 March 2021].

MacLean, C., 2020. Travel Restrictions for Visitors from Eastern Provinces Stay in Place after Pushback from Manitobans [online]. CBC News, 23 July. Available from: https://www. cbc.ca/news/canada/manitoba/manitoba-covid-19-update-thursday-july-23-1.5660359 [Accessed 8 March 2021].

Major, D., 2020. Alberta Premier Jason Kenney Accuses Feds of Getting in the Way of Fixing Contact Tracing App [online]. CBC News, 13 July. Available from: https://www.cbc.ca/ news/politics/kenney-covid-pandemic-contact-tracing-1.5648056 [Accessed 8 March 2021]. 
Marquis, M., 2020. Réouverture de l'économie: Trudeau s'entend avec les provinces et les territoires. La Presse, 16 July. Available from: https://www.lapresse.ca/affaires/ economie/2020-07-16/reouverture-de-l-economie-trudeau-s-entend-avec-les-provinces-etterritoires.php [Accessed 8 March 2021].

McGrath, J.M., 2020. This Is a Global Crisis: Why Is Doug Ford Talking about Who Has Jurisdiction? TVO, 13 November. Available from: https://www.tvo.org/article/this-is-a-globalcrisis-why-is-doug-ford-talking-about-who-has-jurisdiction [Accessed 8 March 2021].

Smiley, D., 1987. The Federal Condition in Canada. Toronto: McGraw-Hill Ryerson.

The Canadian Press, 2020. A Look at What Provinces and Territories Have Said about COVID-19 Vaccine Plans [online]. CityNews, 18 December. Available from: https://toronto. citynews.ca/2020/12/18/a-look-at-what-provinces-and-territories-have-said-about-covid19-vaccine-plans-16/ [Accessed 8 March 2021].

Thorlakson, L., 2009. Patterns of Party Integration, Influence and Autonomy in Seven Federations. Party Politics, 15, 157-177.

Wallner, J., 2017. Ideas and Intergovernmental Relations in Canada. PS: Political Science do Politics, 50 (3), 717-722.

Wright, T., 2020. Feds Probing Ways to Address COVID-19 Impact on Women. CTV News, 23 May. Available from: https://www.ctvnews.ca/politics/feds-probing-ways-to-addresscovid-19-impact-on-women-1.4951560 [Accessed 8 March 2021]. 